\title{
Effect of hypoprolactinaemia and hyperprolactinaemia on LH secretion, endocrine function of testes and structure of seminiferous tubules in boars
}

\author{
M. Jedlinska ${ }^{1}$, L. Rozewiecka ${ }^{2}$ and A. J. Ziecik ${ }^{1 *}$ \\ ${ }^{\mathrm{I}}$ Division of Reproductive Endocrinology and Pathophysiology, Centre for Agrotechnology and Veterinary \\ Sciences, Polish Academy of Sciences, 10-718 Olsztyn, Poland; and ${ }^{2}$ Department of Histology and \\ Embryology, Pomeranian School of Medicine, 70-111 Szczecin, Poland
}

\begin{abstract}
The influence of exogenous prolactin-induced hyperprolactinaemia and bromocriptineinduced hypoprolactinaemia on LH secretion, endocrine function of testes and the structure of seminiferous tubules was investigated in boars. Treatment with exogenous pig prolactin for 21 days $\left(0.07 \mathrm{mg} \mathrm{kg}^{-1}\right.$ day $\left.^{-1} ; n=5\right)$ caused a significant increase in mean prolactin concentrations during the experiment $(P<0.05)$ and during $4 \mathrm{~h}$ sampling $(P<0.01)$. Treatment with bromocriptine $\left(0.2 \mathrm{mg} \mathrm{kg}^{-1}\right.$ per os and $0.05 \mathrm{mg} \mathrm{kg}^{-1}$ i.m.; $\left.n=4\right)$ decreased mean prolactin concentrations throughout the experiment as well as during two $4 \mathrm{~h}$ sampling periods $(P<0.01)$. Treatment with exogenous prolactin decreased mean $\mathrm{LH}$ concentrations during the treatment $(P<0.01)$ and during the first $4 \mathrm{~h}$ sampling period $(P<0.05)$, but did not affect the number of pulses, pulse frequency or amplitude. Bromocriptine did not affect $\mathrm{LH}$ concentrations. Prolactin increased testosterone concentrations during the treatment $(P<0.01)$, while boars treated with bromocriptine had lower testosterone concentrations $(P<0.05)$ than did controls. Both exogenous prolactin and bromocriptine treatments significantly decreased oestradiol concentrations during the course of the experiment. The injections of prolactin and administration of bromocriptine caused a decrease in $L H / h C G$ receptor concentration $(P<0.05)$ in the cell membrane of testes, without causing a change in binding affinity. The bromocriptine treatment caused premature release of some spermatocytes and the presence of polynucleate cells in the seminiferous tubules. In the seminiferous epithelium of hyperprolactinaemic boars, more mature cells (mainly spermatids) were released into the lumen. In tubules in which many polynucleate cells were found, considerable regression of seminiferous epithelium occurred. It is concluded that both hyper- and hypoprolactinaemia disrupt testicular endocrine function and change the process of spermatogenesis in boars. Hyperprolactinaemia has a greater effect on the testes and may decrease the secretion of $\mathrm{LH}$.
\end{abstract}

\section{Introduction}

Prolactin plays an important role in the regulation of testicular function in rodents (Bartke and Dalterio, 1976; Bartke et al., 1977). The physiological role of prolactin in male laboratory mammals includes the regulation of growth and normal function of all tissues sensitive to androgens. Prolactin receptors have been found in Leydig cells of the testes, epididymides and accessory glands (Barkey et al., 1977; Bouhdiba et al., 1989). Prolactin, together with LH and growth hormone $(\mathrm{GH})$, controls the production and maintenance of the LH receptors in the testes (Zipf et al., 1978). Prolactin also increases the capacity of LH receptors and the concentration of cholesterol esters in the testes, creating a pool of precursors used in steroidogenesis. Another important role of prolactin is the

*Correspondence.

Received 10 October 1994. activation of $3 \beta$ - and $17 \beta$-hydroxysteroid dehydrogenase - the key enzymes in the synthesis of testosterone (Musto et al., 1972; Amador and Bartke, 1991; Chandrashekar et al., 1991).

Besides the effect on the endocrine function of the testes, prolactin significantly influences the process of spermatogenesis. There is a correlation between blood and seminal plasma concentrations of this hormone. Prolactin affects some parameters of semen quality such as the amount, motility and capacitation of spermatozoa and their ability to penetrate the ovum (Sheth et al., 1975; Sueldo et al., 1985; Eggert-Kruse et al., 1991). The role of prolactin in male domestic ruminants has not yet been described, except in sheep. In rams, prolactin may affect LH secretion and influence testicular function (Ravault et al., 1977, 1982a; Regisford and Katz, 1993).

The regulation of testicular activity by gonadotrophins has been well documented in boars (Allrich et al., 1983; Berardinelli et al., 1984; Ziecik et al., 1989). The production of prolactin in 
pigs begins on about day 70 of fetal life (Dacheux, 1984; Meijer $e t$ al., 1988). The prematurational surge of prolactin in boars, which occurs about 12 weeks after birth, is connected with the significant increase in gonadotrophin concentration (Meijer et al., 1988). However, the importance of prolactin in the maintenance of testicular function in boars has not been elucidated. This study was therefore performed to determine the effects of exogenous prolactin-induced hyperprolactinaemia and bromocriptine-induced hypoprolactinaemia on $\mathrm{LH}$ secretion, and the endocrine function of the testes as well as on the structure of the seminiferous tubules in boars. Some of the results were communicated in a preliminary form at the 12th International Congress on Animal Reproduction, The Hague, The Netherlands, 23-27 August, 1992.

\section{Materials and Methods}

\section{Animals and experimental procedures}

Thirteen cross-bred boars, 7 months of age, were maintained under conditions of natural light and temperature (September) in individual stalls and fitted with indwelling vena caval cannulae (Kotwica et al., 1978) 3 days before the experiment. The boars were assigned to three groups: (i) hyperprolactinaemic $(n=4)$ given exogenous porcine prolactin, (ii) hypoprolactinaemic $(n=5)$ given bromocriptine and (iii) control $(n=4)$ given saline.

Blood samples were collected twice a day (at 08:00 and 20:00 h) and every $20 \mathrm{~min}$ for $4 \mathrm{~h}(11: 00-15: 00 \mathrm{~h})$ on days 4 and 17 of the experiment. The plasma obtained after centrifugation $\left(1500 \mathrm{~g}, 4^{\circ} \mathrm{C}, 10 \mathrm{~min}\right)$ was stored at $-20^{\circ} \mathrm{C}$ until prolactin, $\mathrm{LH}$, testosterone and oestradiol concentrations were determined. Prolactin, $\mathrm{LH}$ and testosterone were determined in all the samples; oestradiol was measured in the samples taken at 08:00 and 20:00 h every day.

After the last blood collection, all boars were castrated and samples of testes were frozen immediately in liquid nitrogen and either kept until LH receptor assay or fixed in Bouin's solution.

\section{Treatment}

Boars were treated for 21 days. Prolactin purified from pig pituitaries (Biolactin; $19 \mathrm{iu} \mathrm{mg}^{-1}$; a gift of F. Ryszka, Silesian School of Medicine, Zabrze, Poland) was injected i.m. $(0.07 \mathrm{mg}$ $\mathrm{kg}^{-1}$ body mass) in $3 \mathrm{ml}$ of saline. The same dose was used to stimulate lactation in sows (Dusza et al., 1991). Bromocriptine (2-bromo-a-ergocriptine) was given twice a day: at 08:00 h per os in the form of Parlodel (Sandoz, $0.2 \mathrm{mg} \mathrm{kg}^{-1}$ ) and at 20:00 h, $0.05 \mathrm{mg} \mathrm{kg}^{-1}$ i.m. as bromocriptine CB-154 in $3 \mathrm{ml}$ solution (a gift of D. Romer, Sandoz, Pharma). Bromocriptine CB-154 was dissolved in 96\% ethanol and mixed I:I with saline before injection. At similar times control boars were given vehicle only. Doses of bromocriptine CB-154 were selected on the basis of earlier experiments in cows (Bevers and Dieleman, 1987) and sheep (Regisford and Katz, 1993).

\section{Radioimmunoassays}

The plasma concentrations of prolactin were determined by the double-antibody radioimmunoassay described by Dusza and Krzymowska (1979) using the pig prolactin preparation KK-2 as a standard and for iodination. First, antibodies from a goat immunized against pig prolactin (Research Products Int. Corp., Mt Prospect, IL) were used at a titre of 1:40000. Second, antibodies, anti-goat $\gamma$-globulin from immunized rabbits, were used at a 1:20 dilution. The sensitivity of the assay was $0.19 \mathrm{ng} \mathrm{ml}^{-1}$. The intra- and interassay coefficients of variation were $4.2 \%$ and $9.8 \%$, respectively.

Plasma concentrations of $\mathrm{LH}$ were determined by the double-antibody radioimmunoassay method described by Ziecik et al. (1978) with the following modifications. The primary antibodies (Sz/Z/89/396), from the immunized rabbit against a conjugate of pig LH with ovalbumin, were used at a final dilution of 1:1.800000. The crossreactions of antiserum used with different antigens were $2.0 \%$ for pig GH, $1.5 \%$ for bovine TSH and $0.2 \%$ for porcine FSH, but $0.06 \%$ for prolactin and hCG. Purified pig LH (USDA-pLH-1) was used for the preparation of the radioiodinated antigen and USDA-pLH-B-I as a standard. The sensitivity of the assay was $0.08 \mathrm{ng} \mathrm{ml}^{-1}$. Intra- and interassay coefficients of variation were $6.7 \%$ and $11.3 \%$, respectively.

Testosterone concentration was determined by direct assay in plasma diluted 10 times with antibodies from immunized rabbits against a conjugate of 4 -androstene-17 $\beta$-ol-3-one-3(carboxymethyl) oxime:BSA (B. Szafranska and A. J. Ziecik, unpublished data) with $\left[1,2,6,7-{ }^{3} \mathrm{H}\right]$ testosterone (Amersham, Buckinghamshire) as tracer. The crossreactions of antiserum with different antigens were: $5 \alpha$-androstane-17 $\beta$-ol-3-one: $33.3 \%$; 4 -androstane-11 $\beta$-ol-3,17-dione: $\quad 4.0 \% ; \quad 5 \alpha$-androstane-3,17dione and $5 \beta$-androstane- $3 \alpha-17 \beta$-diol: $0.3 \%$; epiandrosterone: $0.1 \%$ and progesterone, androsterone, $5 \beta$-androstane- $3 \alpha-17 \beta-$ dione: $<0.1 \%$. No crossreactions were detected with dehydroepiandrosterone, $5 \alpha$-pregnan-3 $\alpha$-ol-20-one, $5 \alpha$-pregnan$3 \beta$-ol-20-one, 4-pregnan-20 $\beta$-ol-3-one, oestrone, oestradiol and $\beta$-oestradiol-17-propionate. This antibody was determined to have an affinity constant by Scatchard plot of $2.1 \times 10^{10}$ $1 \mathrm{~mol}^{-1}$. The antiserum was used at a titre of 1:20000. The sensitivity of the assay was $0.12 \mathrm{ng} \mathrm{ml}^{-1}$, and intra- and interassay coefficients of variation were $5.6 \%$ and $8.8 \%$, respectively. Oestradiol concentration was determined using an extraction method (Szafranska and Tilton, 1993) with $[2,4,6,7-$ ${ }^{3} \mathrm{H}$ ]oestradiol (Amersham) as tracer. The recovery of oestradiol in the extracted samples was $88 \%$ and the sensitivity of the assay was $5 \mathrm{pg}$ per tube. Intra- and interassay coefficients of variation were $9.0 \%$ and $10.2 \%$, respectively.

\section{Preparation of the membrane fraction and LH/hCG receptor analyses}

Each testicular tissue was dissected, minced with scissors and weighed. The cell membrane fractions were obtained using the procedure described by Ziecik et al. (1986). Each tissue was homogenized twice in bursts of $10 \mathrm{~s}$ at $4^{\circ} \mathrm{C}$ with an Ultra-Turax homogenizer in four volumes $(\mathrm{w} / \mathrm{v})$ of $25 \mathrm{mmol}$ Tris- $\mathrm{HCl}$ buffer $\mathrm{I}^{-1}, \mathrm{pH} 7.4$; containing 0.25 mol sucrose $\mathrm{I}^{-1}$. The homogenate was then filtered through four layers of cheesecloth and the filtrate was centrifuged for $20 \mathrm{~min}$ at $800 \mathrm{~g}$, at $4^{\circ} \mathrm{C}$. The resulting supernatant was centrifuged for a further 
$\mathrm{I} \mathrm{h}$ at $25000 \mathrm{~g}$ at $4^{\circ} \mathrm{C}$ and the sediment suspended in $3 \mathrm{ml}$ ice-cold $25 \mathrm{mmol}$ Tris $-\mathrm{HCl}$ buffer $\mathrm{l}^{-1}, \mathrm{pH} 7.2$ containing $0.1 \%$ $(\mathrm{w} / \mathrm{v}) \mathrm{BSA}$ and $5 \mathrm{mmol} \mathrm{MgCl}_{2} \mathrm{1}^{-1}$. Aliquots of $1 \mathrm{ml}$ of the resulting suspension were stored in liquid nitrogen. A fraction of the receptor preparation was assayed for protein by the method of Lowry et al. (1951).

The cell membrane fraction was incubated with the tracer in polystyrene tubes. Human CG (CR-125) was labelled using the chloramine-T method described by Greenwood and Hunter (1963). The specific activity of [ $\left.{ }^{125} \mathrm{I}\right]$-labelled iodo-hCG was determined by a self-displacement in a radioligand receptor assay and was $55 \mu \mathrm{Ci} \mu \mathrm{g}^{-1}$. The maximum binding was $40 \%$. Nonspecific binding was measured by the addition of $1 \mu \mathrm{g}$ unlabelled hCG and was $<2 \%$ of the total ${ }^{125}$ I-labelled hCG added. The incubation mixture consisted of $0.1 \mathrm{ml} 5 \mathrm{mmol}$ Tris- $\mathrm{HCll}^{-1}$ (pH 7.2) containing $5 \mathrm{mmol} \mathrm{MgCl} \mathrm{l}^{-1}$ and $0.1 \%$ $(\mathrm{w} / \mathrm{v})$ BSA (incubation buffer), $0.1 \mathrm{ml}$ incubation buffer containing 20000 c.p.m. ${ }^{125}$ I-labelled hCG $\mathrm{min}^{-1}$, and $0.2 \mathrm{ml}$ receptor preparation containing $0.6-1.0 \mathrm{mg}$ protein. After incubation overnight at room temperature, $1.5 \mathrm{ml}$ of ice-cold Tris- $\mathrm{HCl}$ buffer was added and the tubes were centrifuged at $1000 \mathrm{~g}$ for $30 \mathrm{~min}$. The concentrations of unoccupied binding sites and equilibrium association constants $\left(K_{\mathrm{a}}\right)$ were determined by Scatchard analysis using the EBDA computer program (Elsevier, BIO-SOFT, Cambridge). Seven subsaturating quantities of unlabelled hCG $(0.01-5 \mathrm{ng})$ were used for each receptor preparation. The sensitivity of the receptor assay was $0.15 \mathrm{fmol}$ $\mathrm{mg}^{-1}$ protein.

\section{Histology}

Tissue specimens were fixed with Bouin's solution, embedded, serially sectioned at $7 \mu \mathrm{m}$ and stained routinely with haematoxylin-eosin and periodic acid-Schiff's reagent. Examination of the morphology of the testes was based on the cycle of the seminiferous epithelium described in boars by Swierstra (1968). The stage of epithelium cycle was assessed by analysis of the transverse sections of seminiferous tubules.

\section{Statistical analyses}

The mean hormone concentrations were obtained by averaging the values, for each animal, for all 42 samples taken every day at 08:00 and 20:00 h. The concentrations of plasma prolactin, $\mathrm{LH}$ and testosterone were also averaged for the two $4 \mathrm{~h}$ sampling periods (13 samples) for each animal. The number of peaks, hormone peak frequency and peak amplitude during the $4 \mathrm{~h}$ were determined using the EPISTAT programme (Statistical Package, Version 3.0, Round Rock, TX).

Consecutively, the collected data were compared by analysis of variance (ANOVA) to establish the overall effects of treatment (prolactin-treated, bromocriptine-treated and control). In addition, comparisons of means were performed by Duncan's multiple-range test.

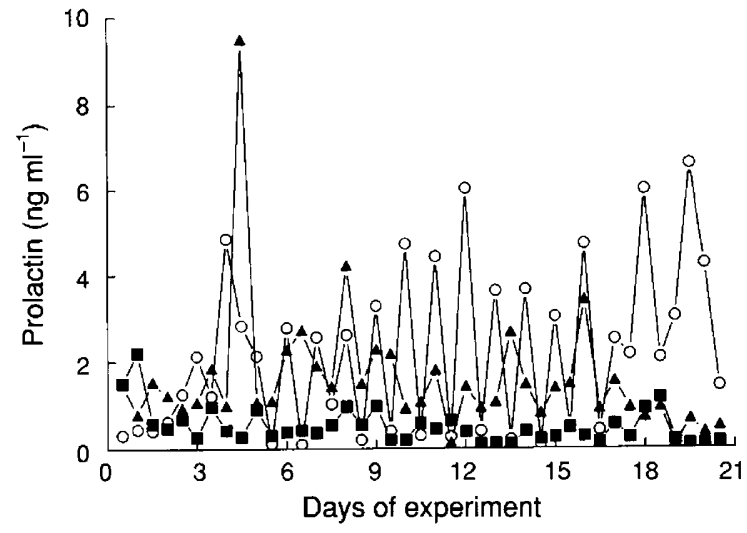

Fig. 1. Mean concentrations of prolactin in boars treated with (o) pig prolactin $(n=4$; SEM \pm 0.2$)$, ( $)$ bromocriptine $(n=5$; SEM \pm 0.04$)$ or $(\Lambda)$ saline vehicle $(n=4 ; \operatorname{SEM} \pm 0.1)$

\section{Results}

Effect of exogenous prolactin and bromocriptine on prolactin, $L H$, testosterone and oestradiol concentrations

Prolactin. The analysis of plasma samples taken twice a day demonstrated that both exogenous prolactin and bromocriptine affected prolactin concentrations (Fig. 1). The injections of exogenous prolactin caused a significant increase $(P<0.05)$ in mean $\left(2.2 \pm 0.2 \mathrm{ng} \mathrm{ml}^{-1}\right)$ plasma concentrations of prolactin compared with control values of $1.6 \pm 0.2 \mathrm{ng} \mathrm{ml}^{-1}$. Higher concentrations of prolactin $(P<0.01)$ were found during the $4 \mathrm{~h}$ sampling period on day 4 and day 17 of the experiment (Fig. 2). The bromocriptine treatment significantly decreased $(P<0.01)$ mean prolactin concentrations to $0.50 \pm 0.06 \mathrm{ng}$ $\mathrm{ml}^{-1}$ during the whole period of the experiment. A similar depletion of prolactin concentrations was found during both $4 \mathrm{~h}$ sampling periods $(P<0.01$; Fig. 2).

Luteinizing hormone. Exogenous prolactin clearly decreased $(P<0.01)$ the mean $\mathrm{LH}$ concentrations from $0.53 \pm 0.03 \mathrm{ng}$ $\mathrm{ml}^{-1}$ to $0.34 \pm 0.01 \mathrm{ng} \mathrm{ml}^{-1}$ during the whole period of the experiment (Fig. 3). The injections of prolactin caused a decrease in mean LH concentrations on day $4(P<0.05)$ but did not affect them on day $17 \quad 0.64 \pm 0.03$ compared with $0.72 \pm 0.04 \mathrm{ng} \mathrm{ml}^{-1}$ in control) (Table 1). The number of pulses, pulse frequency and amplitude remained unchanged throughout both sampling periods. Bromocriptine did not affect LH concentrations during the whole period of the experiment (Fig. 3) or during the $4 \mathrm{~h}$ sampling periods.

Testosterone and oestradiol. Exogenous prolactin increased testosterone concentrations during the treatment $(P<0.01)$ from $1.9 \pm 0.1$ to $2.8 \pm 0.02 \mathrm{ng} \mathrm{ml}^{-1}$. Boars treated with bromocriptine preparations had lower testosterone concentrations $\left(1.6 \pm 0.09 \mathrm{ng} \mathrm{ml}^{-1} ; P<0.05\right)$ than did controls. The twice daily recorded data revealed variable testosterone secretion in boars tested. The daily range of blood testosterone concentrations varied from $0.25 \pm 0.01$ to $3.76 \pm 0.16$, $0.52 \pm 0.02$ to $3.10 \pm 0.20$ and $0.75 \pm 0.03$ to $7.20 \pm 0.52 \mathrm{ng}$ $\mathrm{ml}^{-1}$ in control, bromocriptine- and prolactin-treated animals, respectively, over the 21 days of the experiment. Analysis of 


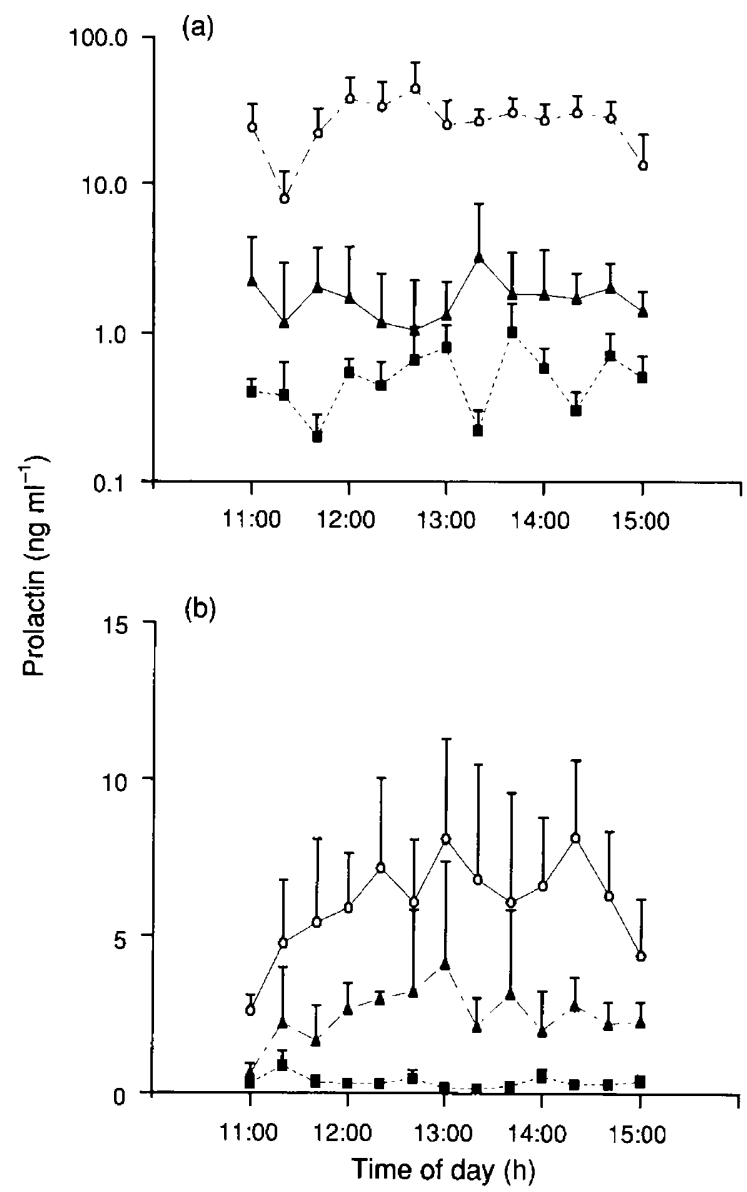

Fig. 2. Mean concentrations of prolactin in boars treated with (o) pig prolactin $(n=4),(\square)$ bromocriptine $(n=5)$ or $(\Lambda)$ saline vehicle $(n=4)$ during frequent sampling periods on (a) day 4 and (b) day 17 of the experiment. Values are means \pm SEM.

the $4 \mathrm{~h}$ periods of collection did not show changes in pulse characteristics. Exogenous prolactin reduced $(P<0.01)$ oestradiol concentrations in the blood by about $20 \%$ compared with saline-treated boars $\left(76.4 \pm 2.4\right.$ versus $61.9 \pm 1.7 \mathrm{pg} \mathrm{ml}^{-1}$; Fig. $3)$. In addition, the bromocriptine treatment significantly decreased $(P<0.05)$ oestradiol concentrations during the course of the experiment.

\section{LH/hCG receptors in cell membrane preparations of boar testes}

The injections of exogenous prolactin as well as the administration of bromocriptine caused a decrease in LH/hCG receptor content $(P<0.05)$ in the cell membranes of the testes of the treated boars compared with the control group. In hyperprolactinaemic boars, $\mathrm{LH} / \mathrm{hCG}$ receptor content decreased from $13.5 \pm 4.2$ to $7.6 \pm 1.3 \mathrm{fmol} \mathrm{mg}^{-1}$ protein. The content of $\mathrm{LH} / \mathrm{hCG}$ receptors in animals given bromocriptine was $50 \%$ of control values $\left(6.8 \pm 1.2 \mathrm{fmol} \mathrm{mg}^{-1}\right.$ protein). In both groups, the decrease in $\mathrm{LH}$ binding by receptors occurred without a change in binding affinity. Association contents $\left(K_{\mathrm{a}}\right)$ for prolactin, bromocriptine and the control group were 5.0 \pm 1 .1, $5.3 \pm 0.9$ and $4.6 \pm 1.0 \times 10^{10} \mathrm{lmol}^{-1}$, respectively.

\section{Histology}

The examination of seminiferous epithelium in control boars (Fig. 4a) revealed the presence of all generations and layers of germinal cells in stages from I to VIII. The bromocriptine treatment did not cause many changes on the seminiferous tubule transections. The premature release of spermatocytes into the lumen of the tubule and the presence of polynucleate cells was sporadically observed. One boar from the bromocriptine-treated group showed more intensive changes and there were more polynucleate cells than in the other animals (Fig. 4b).

The injections of exogenous prolactin caused the most intensive changes in the testes. Seminiferous epithelium showed empty sites left by released cells (Fig. 4c). The more mature cells, mainly spermatids at various stages of differentiation but also occasional pachytene spermatocytes, were flaked off. Many polynucleate cells were observed in the seminiferous epithelium as well as in the lumen of the tubule. In some tubules, especially those in which many polynucleate cells were found, considerable regression of seminiferous epithelium occurred (Fig. 4d).

\section{Discussion}

The study reported here determined the effect of prolactininduced hyperprolactinaemia and bromocriptine-induced hypoprolactinaemia on LH secretion and testicular function in boars. The experiment was performed on mature animals when the prolactin concentration in the blood had stabilized after a prepubertal period (10-16 weeks) and pubertal peaks (20-22 weeks; Meijer et al., 1988). Significant changes in the concentration of circulating prolactin in treated animals were then induced by exogenous prolactin or administration of bromocriptine. The concentrations of $\mathrm{LH}$ in control animals were similar to those reported by Liptrap et al. (1986) in adult boars. The results from twice daily sampling show that injections of exogenous prolactin decreased mean plasma concentration of LH by $34 \%$; however, this suppression was short lived, presenting at 4 but not at 17 days.

An inhibitory effect of exogenous prolactin on concentrations of LH is found in pregnant gilts (Szafranska and Ziecik, 1990). Hyperprolactinaemia, induced by haloperidol during the second half of pregnancy, also drastically suppresses LH secretion in pigs (Szafranska and Tilton, 1993). Exogenous prolactin exerts a dose-dependent suppression of postcastration LH secretion in male rats (Park and Selmanoff, 1991). Prolactin is thus involved in the control of the hypothalamo-pituitary axis. Its effect on LH secretion is probably transmitted via activation of a dopaminergic part of the hypothalamus. High concentrations of prolactin cause an increase in dopamine turnover in the medial basal hypothalamus and a decrease in GnRH secretion from the hypothalamus and, consequently, LH release from the pituitary (Gudelsky et al., 1976; Moult et al., 1982; Koike et al., 1991). It is also possible that LH concentrations in the prolactin-injected boars have been reduced owing to increased plasma concentrations of testosterone exerting negative feedback at the hypothalamus or pituitary. The interrelation between LH and prolactin seems to differ 

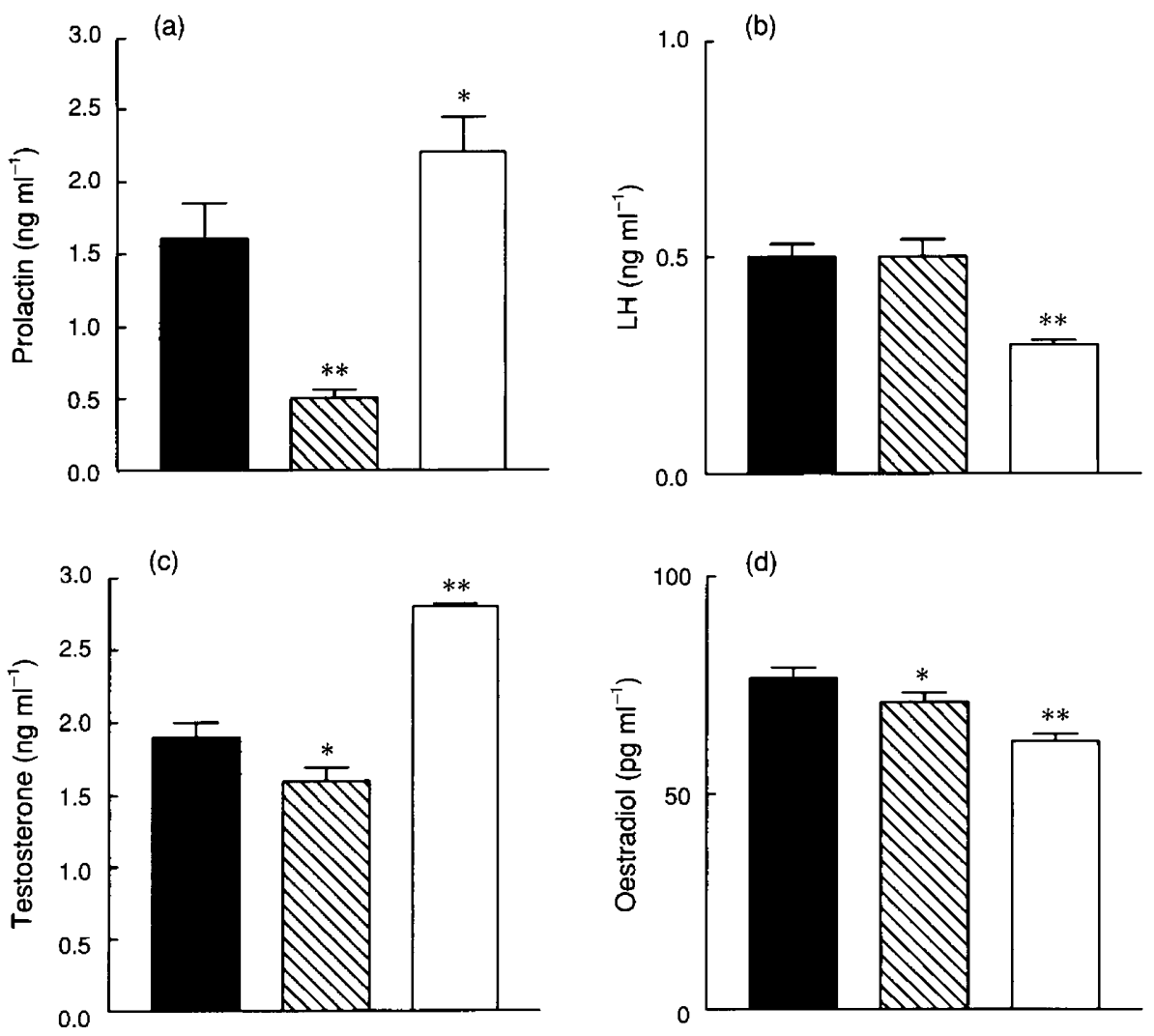

Fig. 3. Mean plasma concentrations of (a) prolactin, (b) LH, (c) testosterone and (d) oestradiol during 21 days of the experiment in boars treated with $(\square)$ pig prolactin $(n=4)$, ( $(\nabla)$ bromocriptine $(n=5)$, or $(\mathbb{\square})$ saline vehicle $(n=4)$. Values are means \pm SEM. Means are significantly different between treated and control boars within the experimental period $\left({ }^{*} P<0.05,{ }^{* *} P<0.01\right)$.

Table 1. Mean hormone concentrations, peak frequency and peak amplitude in prolactin-treated, bromocriptine-treated and control boars during the $4 \mathrm{~h}$ sampling period on day 4 of the experiment

\begin{tabular}{llccc}
\hline & & \multicolumn{3}{c}{ Day 4} \\
\cline { 3 - 4 } Hormone & \multicolumn{1}{c}{ Treatment } & $\begin{array}{c}\text { Mean } \\
\left(\mathrm{ng} \mathrm{ml}^{-1}\right)\end{array}$ & $\begin{array}{c}\text { Peak frequency } \\
\text { (peaks in } 4 \mathrm{~h})\end{array}$ & $\begin{array}{c}\text { Peak amplitude } \\
\left(\mathrm{ng} \mathrm{ml}^{-1}\right)\end{array}$ \\
\hline $\mathrm{LH}$ & Prolactin & $0.51 \pm 0.04^{*}$ & $2.75 \pm 0.25$ & $0.91 \pm 0.22$ \\
& Bromocriptine & $1.04 \pm 0.06$ & $3.20 \pm 0.37$ & $1.39 \pm 0.24$ \\
Testosterone & Control & $0.93 \pm 0.10$ & $2.25 \pm 0.62$ & $1.74 \pm 0.66$ \\
& Prolactin & $0.72 \pm 0.04$ & $2.50 \pm 0.29$ & $0.67 \pm 0.17$ \\
& Bromocriptine & $1.09 \pm 0.04$ & $2.00 \pm 0.70$ & $1.36 \pm 0.17$ \\
& Control & $1.12 \pm 0.07$ & $1.75 \pm 0.25$ & $1.46 \pm 0.48$ \\
\hline
\end{tabular}

Values are means \pm SEM.

*Means are significantly different between treatment groups within the sampling period.

depending on the age of the animal. In prepubertal rats, neither hyper- nor hypoprolactinaemia affects the concentration of $\mathrm{LH}$ in serum. In these animals, hyperprolactinaemia reduces only the secretion of FSH (Chandrashekar et al., 1987). In 12-weekold boars, the pubertal surge of prolactin occurs together with increased concentrations of gonadotrophins but low concentrations of testosterone (Meijer et al., 1988).

In the study reported here exogenous prolactin increased the concentrations of testosterone but decreased the concentra- tions of oestradiol in plasma in blood samples taken twice a day but no treatment effect was found during intensive sampling periods. The discrepancies between the data obtained twice a day and the data based on intensive sampling can be explained by the variable pulsatile secretion of testosterone in intact boars (Liptrap et al., 1986) and by the different daily hours of blood collection. It is suggested that prolactin may have a direct effect on the aromatization of androgens in the human testes (Magrini et al., 1976; Martikainen and Vihko, 

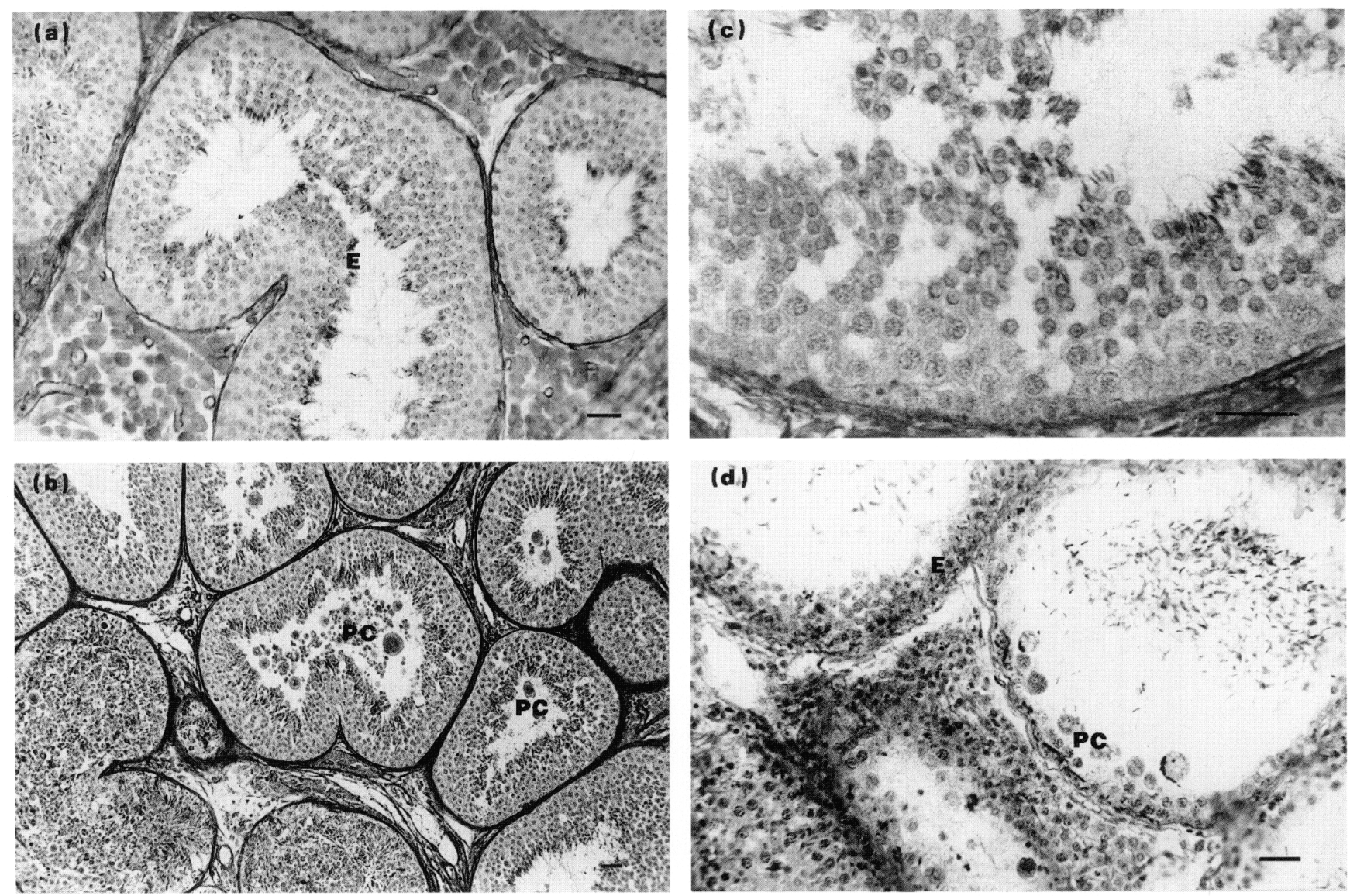

Fig. 4. Photomicrographs of testicular tissue from (a) a normal control boar. Histology of seminiferous epithelium (E) is normal and germ cells conform to normal cellular associations of the spermatogenic cycle; (b) bromocriptine-treated boar showing presence of polynucleate cells (PC) in the lumen of seminiferous tubules; (c, d) hyperprolactinaemic boars. Exogenous prolactin caused: (c) premature release of germ cells and (d) the appearance of many polynucleate cells (PC) and regression of the seminiferous epithelium (E). Scale bars represent $25 \mu \mathrm{m}$.

1982). The increase of testosterone during hyperprolactinaemia is also found in men (Magrini ef al., 1976), rats (Hafiez et al., 1972; Bartke et al., 1977) and hamsters (Bartke et al., 1985). A high concentration of prolactin can also disrupt the conversion of testosterone to its active metabolite 5- $\alpha$ dihydrotestosterone (Katovich et al, 1985). However, in prepubertal rats the increase in oestradiol concentrations induced by prolactin is preceded by an increase in the concentration of testosterone in the plasma, but only in the presence of FSH (Pomerantz, 1983). Prolactin alone does not induce a synthesis of steroids in hypophysectomized animals (Klemcke et al., 1990). The administration of bromocriptine did not induce any significant changes in the secretion of LH in boars. A similar lack of effect of bromocriptine on $\mathrm{LH}$ is found in cyclic sows (Dusza et al., 1983). However, bromocriptine treatment did decrease the plasma concentrations of testosterone and oestradiol. This may indicate the direct testicular effect of bromocriptine. There were no differences in the profiles of $\mathrm{LH}$ and testosterone secretion during the $4 \mathrm{~h}$ period of blood sampling on days 4 and 17 of the experiment between the treated and control boars. The main reason for this is, perhaps, the variability of the pulsatile secretion of $\mathrm{LH}$ (Liptrap et al., 1986).
The concentrations of LH receptor sites in boar testes reached a maximum at the age of between 20 and 70 days, decreased at the onset of puberty (up to 110 days) and reached a stable concentration in adults (Peyart et al., 1981). The binding capacity of testicular tissue, expressed as $\mathrm{fmol} \mathrm{mg}^{-1}$ membrane protein, is greatest at the age of 100 days, decreases linearly until day 190 and then remains stable for the next 250 days (Berardinelli et al., 1984). In the present study, both prolactin and bromocriptine caused a significant decrease in concentrations of $\mathrm{LH} / \mathrm{hCG}$ receptors in the boar testes. The stimulatory effect of prolactin on $\mathrm{LH} / \mathrm{hCG}$ receptors may have been overridden by the consequences of reduced LH concentrations. The above results can be explained not only by the direct effect of prolactin, but also by changes in gonadotrophin and steroid hormone secretion. The direct effect of bromocriptine on $\mathrm{LH} / \mathrm{hCG}$ binding sites cannot be excluded (Amador and Bartke, 1991).

Hyperprolactinaemia has different effects on testicular LH/hCG receptor concentrations in various species, causing a decrease in mice numbers (Klemcke and Bartke, 1981; Takase et al., 1990), no effect in rams (Barenton and Pelletier, 1980) and an increase in rats (Sharpe et al., 1980). Bromocriptine affects $\mathrm{LH} / \mathrm{hCG}$ receptors more uniformly, causing a decrease in their 
concentration in the testes of adult mice (Takase et al., 1990), rats (Aragona et al., 1977), hamsters (Amador and Bartke, 1991) and pigs (this study) but not in rams (Barenton and Pelletier, 1980).

High concentrations of prolactin are often associated with regression of the seminiferous epithelium, oligospermia and a decrease in the lifespan of spermatozoa (Cameron et al., 1984; Chandrashekar and Bartke, 1988). Hyperprolactinaemia causes a reduction in fertility by producing changes in the process of spermatogenesis, low quality semen and a decrease in libido in many species (Segal et al., 1979; Katovich et al., 1985; EggertKruse et al., 1991; Gonzales et al., 1992). The study reported here showed for the first time that prolactin-induced hyperprolactinaemia causes a strong disturbance of spermatogenesis in boars. The bromocriptine treatment did not influence the seminiferous epithelium to the same extent. In wild boars, in contrast to males of domesticated breeds of pig, plasma concentrations of prolactin vary with season; and the highest concentrations occur in July and the lowest during the winter months (Ravault et al., 1982b). During the summer months, wild boars as well as sows show sexual inactivity. It has not been clearly demonstrated that prolactin causes anoestrus in wild pigs. Normal physiological plasma concentrations of prolactin, as have been shown in this study, are important in the regulation of gonadotrophin and testicular steroid secretion and in the function of seminiferous epithelium in boars. It is, therefore, possible that hyperprolactinaemia observed during long daylength is a reason for seasonal infertility in wild boars and the sporadically reported decrease in semen quality in some domesticated pigs during the summer months.

In summary, this study has shown the importance of normal physiological secretion of prolactin on reproduction in boars. Both hyper- and hypoprolactinaemia disrupt testicular endocrine function and change the process of spermatogenesis. However, hyperprolactinaemia causes a more severe effect on the testes and also influences the secretion of $\mathrm{LH}$. These results support the hypothesis that there is an inverse relationship between $\mathrm{LH}$ and prolactin secretion in pigs.

The authors thank F. Ryszka (Zabrze, Poland) for the pig prolactin, D. Romer (Sandoz, Pharma) for bromocriptine CB-154, D. Bolt (USDA Hormone Program) for pig pituitary hormones.

\section{References}

Allrich RD, Christenson RK, Ford JJ and Zimmerman DR (1983) Pubertal development of the boar: age-related changes in testicular morphology and in vitro production of testosterone and estradiol-17 $\beta$ Biology of Reproduction $28902-909$

Amador AG and Bartke A (1991) Effects of in vivo and in vitro exposure to bromocryptine on testicular $\mathrm{L}, \mathrm{H}$ receptors and in vitro testosterone production in Syrian hamsters Revista Espanola de Fisiologia 47 121-128

Aragona C, Bohnet HG and Friesen HG (1977) Localization of prolactin binding in prostate and testis: the role of serum prolactin concentration on the testicular LH receptor Acta Endocrinologica 84 402-409

Barenton B and Pelletier J (1980) Prolactin, testicular growth and LH receptors in the ram following light and 2-BR- $\alpha$-ergocryptine (CB-154) treatments Biology of Reproduction 22 781-790

Barkey RJ, Shani J, Amit T and Barzilai D (1977) Specific binding of prolactin to seminal vesicle, prostate and testicular homogenates of immature, mature and aged rats Journal of Endocrinology 74 163-173

Bartke A and Dalterio S (1976) Effects of prolactin sensitivity of the testis to LH Biology of Reproduction 15 90-93
Bartke A, Smith MS, Michael SD, Peron FG and Dalterio S (1977) Effects of experimentally-induced chronic hyperprolactinemia on testosterone and gonadotropin levels in male rats and mice Endocrinology 100 182-186

Bartke A, Klemcke H and Matt K (1985) Effects of physiological and abnormally elevated prolactin levels on the pituitary-testicular axis Medical Biology 63 264-272

Berardinelli JG, Allrich RD, Ford JJ, Christenson RK and Anderson LL (1984) Characterization of luteinizing hormone-human chorionic gonadotropin receptor and its relationship to testicular development and steroidogenesis during sexual maturation in boars Biology of Reproduction 31 541-547

Bevers MM and Dieleman SJ (1987) Effect of chronic treatment with bromocryptine on the corpus luteum function of the cow Animal Reproduction Science 14 95-101

Bouhdiba M, Leroy-Martin B, Peyart JP, Saint Pol P, Dijane J and Leonardinelli J (1989) Immunohistochemical detection of prolactin and its receptors in human testis Andrologia 21 223-228

Cameron F, Murray FT and Drylie DD (1984) Ultrastructural lesions in testes from hyperprolactinemic men Journal of Andrology 5 283-293

Chandrashekar V and Bartke A (1988) Influence of endogenous prolactin on the luteinizing steroidogenesis and the role of prolactin in adult male rats Steroids $\mathbf{5 1}$ 559-576

Chandrashekar V, Bartke A and Sellers K (1987) Prolactin modulates the gonadotropin response to the negative feedback effect of testosterone in immature male rats Endocrinology 10 758-763

Chandrashekar V, Bartke A and Wagner TE (1991) Interactions of human growth hormone and prolactin on pituitary and Leydig cell function in adult transgenic mice expressng the human growth hormone gene Biology of Reproduction 44 135-140

Dacheux F (1984) Differentiation of cells producing polypeptide hormones $(\mathrm{ACTH}, \mathrm{MSH}, \mathrm{LPH}, \alpha-$ and $\beta$-endorphin, $\mathrm{GH}$ and PRL) in fetal porcine anterior pituitary Cell Tissue Research 235 615-621

Dusza L and Krzymowska H (1979) Plasma protein concentrations during the oestrous cycle of sows Journal of Reproduction and Fertility 57 511-514

Dusza L, Krzymowska H, Kotwica G, Ziecik A and Tilton JE (1983) Prolactin, progesterone and luteinizing hormone secretion after bromocriptine (CB154) treatment in cyclic sows Theriogeneology 20 529-535

Dusza L, Sobczak J, Jana B, Murdza A and Bluj W (1991) Zastosowanie Biolactinu-2 (oczyszczona prolaktyna świni) do stymulacji laktacji u loch Medycyna Weterynaryjna 47 418-421

Eggert-Kruse W, Schwalbach B, Gerhard I, Tilgen W and Runnenbaum B (1991) Influence of serum prolactin on semen characteristics and sperm function International Joumal of Fertility 36 243-251

Gonzales GF, Garcia-Hjarles M and Velasquez G (1992) Hyperprolactinaemia and hyperserotoninaemia: their relationship to seminal quality Andrologia 24 95-100

Greenwood FC and Hunter WM (1963) The preparation of ${ }^{12.3}$ I-labelled human growth hormone of high specific radioactivity Biochemical Journal $\mathbf{8 9}$ 114-123

Gudelsky GA, Simpkins J, Mueller GP, Meites J and Moore KE (1976) Selective actions of prolactin on catecholamine turnover in the hypothalamus and on serum LH and FSH Endocrinology 22 206-215

Hafiez AA, Lloyd CW and Bartke A (1972) The role of prolactin in the regulation of testis function: the effects of prolactin and luteinizing hormone on the plasma levels of testosterone and androstenedione in hypophysectomized rats Journal of Endocrinology 52 327-332

Katovich MJ, Cameron F, Murray FT and Gunsalus GL (1985) Alterations of testicular function induced by hyperprolactinemia in the rat Journal of Andrology 6 179-189

Klemcke HG and Bartke A (1981) Effects of chronic hyperprolactinemia in mice on plasma gonadotropin concentrations and testicular human chorionic gonadotropin binding sites Endocrinology 108 1763-1768

Klemcke HG, Amador AG and Bartke A (1990) Hormonal regulation of testicular prolactin receptors and testosterone synthesis in golden hamsters Biology of Reproduction 43 162-168

Koike K, Miyake A, Aono T, Sakumoti T, Ohmichi M, Yomaguchio $M$ and Tanizawa $O$ (1991) Effect of prolactin on the secretion of hypothalamic GnRH and pituitary gonadotropins Hormone Research 35 5-12

Kotwica J, Krzymowski T and Debek J (1978) Kaniulizowanie naczyń zylnych do badań endokrynologicznych Medycyna Weterynaryjna 34 118-120

Liptrap RM, Doble E and Cheng KW (1986) Plasma concentration profiles of gonadotrophins and testosterone in the adult boar Canadian Journal of Veterinary Research $50427-432$ 
Lowry OH, Rosenbrough NJ, Farr AL and Randall RJ (1951) Protein measurement with the folin phenol reagent Joumal of Biological Chemistry 193 265-275

Magrini G, Ebiner JR, Burckhardt P and Felber JP (1976) Study of the relationship between plasma prolactin levels and androgen metabolism in man Journal of Clinical Endocrinology and Metabolism 43 944-947

Martikainen H and Vihko R (1982) hCG-stimulation of testicular steroidogenesis during induced hyper- and hypoprolactinaemia in man Clinical Endocrinology $16 \quad 227-234$

Meijer JC, Trudeau VL, Colenbrander B, Poot P, Erkens JHF and van der Wiel DMF (1988) Prolactin in the developing pig Biology of Reproduction 39 264-269

Moult PJA, Rees LH and Besser GM (1982) Pulsatile gonadotropin secretion in hyperprolactinemic amenorrhea and the response to bromocriptine therapy Clinical Endocrinology 16 153-162

Musto N, Hafiez AA and Bartke A (1972) Prolactin increases 17 $\beta$ hydroxysteroid dehydrogenase activity in the testis Endocrinology 91 1106-1108

Park SK and Selmanoff M (1991) Dose-dependent suppression of postcastration luteinizing hormone secretion exerted by exogenous prolactin administration in male rats: a model for studying hyperprolactinemic hypogonadism Neuroendocrinology $\mathbf{3} 3$ 404-410

Peyart JP, Meusy-Dessolle N and Garnier J (1981) Changes in Leydig cells and luteinizing hormone receptors in porcine testis during postnatal development Endocrinology 108 625-631

Pomerantz DK (1983) Interactions of follicle-stimulating hormone and luteinizing hormone in controlling estradiol synthesis by the testis of the infant rat Biology of Reproduction 28 890-896

Ravault JP, Courot M, Garnier D, Pelletier J and Terqui M (1977) Effect of 2-bromo- $\alpha$-ergocryptine (CB-154) on plasma prolactin, $\mathrm{LH}$ and testosterone levels, accessory reproductive glands and spermatogenesis in lambs during puberty Biology of Reproduction 17 192-197

Ravault JP, Barenton B, Blanc M, Daveau A, Garnier DH, Ortavant R, Pelletier I, de Reviers M-M and Terqui M (1982a) Influence of 2-Br- $\alpha$-ergocryptine (CB154) on the secretion of prolactin, LH, FSH and testosterone and on testicular growth in rams subjected to different photoperiods Reproduction, Nutrition Développerment 22 989-998

Ravault JP, Martinat-Botte F, Mauget R, Martinat N, Locatelli A and Bariteau F (1982b) Influence of the duration of daylight on prolactin secretion in the pig: hourly rhythm in ovariectomized females, monthly variation in domes- tic (male and female) and wild strains during the year Bioiogy of Reproduction 27 1084-1089

Regisford EGC and Katz LS (1993) Effects of bromocriptine-induced hypoprolactinaemia on gonadotrophin secretion and testicular function in rams $\{$ Ovis aries) during two seasons Journal of Reproduction and Fertility 99 529-537

Segal S, Yaffe H, Laufer N and Ben-David M (1979) Male hyperprolactinaemia effects of fertility Fertility and Sterility 32 556-561

Sharpe RM, McNeilly AS, Davidson DW and Swanston IA (1980) Leydig cell function in hyperprolactinaemic adult rats Journal of Endocrinology $8728 \mathrm{P}$

Sheth AR, Mugatwala PP, Shah BG and Rao SS (1975) Occurrence of prolactin in human semen Fertility and Sterility 26 905-907

Sueldo CE, Berger T, Kletzky O and Marrs RP (1985) Seminal prolactin concentration and sperm productive capacity Fertility and Sterility $\mathbf{4 3}$ 632-635

Swiestra EE (1968) Cytology and duration of the cycle of the seminiferous epithelium of the boar; duration of spermatozoa transit through the epididymis Anatomical Record 161 171-186

Szafranska B and Tilton JE (1993) Prolactin as a luteotrophin during late pregnancy in pigs Journal of Reproduction and Fertility 98 643-648

Szafranska B and Ziecik A (1990) Effect of bromocriptine administration during midpregnancy on the ovary function in the pig Experimental and Clinical Endocrinology 96 317-320

Takase M, Tsutsui K and Kawashima S (1990) Effects of prolactin and bromocriptine on the regulation of testicular luteinizing hormone receptors in mice Journal of Experimental Zoology 56 200-209

Ziecik A, Goralska M, Krzymowski T and Pogorzelski K (1978) Isolation and purification of porcine LH for radioimmunoassay and radioreceptor assay Bulletin de l'Academie Polonaise de Sciences 26 739-744

Ziecik AJ, Stanchev PD and Tilton JE (1986) Evidence for the presence of luteinizing hormone/human chorionic gonadotropin-binding sites in porcine uterus Endocrinology 119 1159-1163

Ziecik AJ, Esbenshade KL and Britt JH (1989) Effects of a gonadotrophinreleasing hormone antagonist on gonadotrophin secretion and gonadal development in neonatal pigs Journal of Reproduction and Fertility $\mathbf{8 7}$ 281-289

Zipf WB, Payne AH and Kelch RP (1978) Prolactin, growth hormone and luteinizing hormone in maintenance of testicular luteinizing hormone receptors Endocrinology $103595-600$ 